\title{
Othello the Traveller
}

\begin{abstract}
When a traveller returneth home .... let his travel appear rather in his discourse than in his apparel or gesture; and in his discourse let him be rather advised in his answers, than forwards to tell stories.
\end{abstract}

Among the changes made to his primary narrative source for Othello, Giraldi Cinthio's Hecatommithi (1565), Shakespeare transferred a signal character trait from the Italian tale's Ensign to the English tragedy's eponymous protagonist. In Cinthio's version of events, the unnamed Moor is 'personally valiant and had given proof in warfare', but does not regale his Venetian hosts with amazing stories (for example, in his wooing of Disdemona, who was simply prompted by his 'good qualities' to fall in love with him). ${ }^{2}$ Cinthio's 'false' Ensign, on the other hand, conceals a 'scoundrelly nature' behind a pseudoheroic exterior: 'he so cloaked the vileness hidden in his heart with high sounding and noble words, and by his manner, that he showed himself in the likeness of a Hector or an Achilles' (373). Arden 3 editor E.A.J. Honigmann directs readers to note verbal echoes of this passage in Othello 1.1.12-13 (in which Iago complains that Othello speaks 'with a bombast circumstance / Horribly stuffed with epithets of war') and 2.1.220-1 (in which Iago sneers, 'she first loved the Moor, but for bragging and telling her fantastical lies'), but the editor does not comment further on the reversal whereby Othello is accused of being a deceptive braggart, and Iago claims to be a plain-speaking soldier.

Prompted by Shakespeare's alteration of his source, I shall treat Iago's last comment, not as a frivolous jibe to be dismissed, but as a serious hypothesis to be tested. Why would Othello's enemies (Roderigo, Brabantio and Iago) accuse the general of being 'an extravagant and wheeling stranger' (1.1.134), of using witchcraft and 'foul charms' (1.2.73), and of bragging and telling 'fantastical lies' (2.1.221), if Othello didn't occasionally embellish elements of his life story in order to impress his auditors? For at least some of Shakespeare's Venetians, Othello is simply a traveller telling fantastic tales; 
the question is, might he have appeared thus to early playgoers? In Cinthio's story the couple's disputed love token is a 'handkerchief embroidered most delicately in the Moorish fashion' (378) - already fairly exotic, to be sure; but Othello spices up its provenance in two conflicting stories, one of which details a mythical heirloom sewed in a 'prophetic fury' by a centuries-old Egyptian Sybil (3.4.74). Playgoers initially skeptical of its magical properties (it's supposed to ward off sexual jealousy) would immediately see it have the opposite effect on another couple:

BIANCA. This is some token from a newer friend!

CASSIO. You are jealous now.

Such contradictions in Othello's stories do not stem from slips of Shakespeare's pen, or from typesetting / editorial errors, as is sometimes asserted. Instead, the instability of these stories alerts us to their essentially fictive nature. Othello simply makes things up (such as the provenance of his hidden sword, in the final scene), then mis-remembers the details (was it forged in Toledo, or in Innsbruck?). Despite a fondness for embellishment, Othello insists, in the case of the handkerchief, that his stories are 'true' and 'Most veritable' $(3.4 .71,78)$. In so doing, he illustrates the relativism of Montaigne's adage, 'Nowadaies, that is not the truth which is true, but that which is perswaded to others'. ${ }^{3}$

In a companion article called 'Othello the Liar', I employ Francis Bacon's categories of secrecy, simulation and dissimulation to sift through Othello's statements, and uncover more than thirty lies - some seemingly insignificant, others deadly serious - uttered by a man who claims to cherish honesty and despise hypocrisy. ${ }^{4}$ In this present study, I will elaborate on Bacon's concept of simulation, or 'false profession,' to discuss Othello the traveller and the significance of his penchant for telling wondrous tales. Defined by Bacon as 'when a man industriously and expressly feigns and pretends to be that he is not' (VI.19-20), simulation is a kind of affirmative untruth in which perpetrators invent false materials, embellish their achievements or exaggerate their talents in order to achieve self-promotional goals - actions akin to padding one's resumé today. Perez Zagorin highlights differences between the two terms: 'in a strict sense dissimulation is pretending not to be what one actually is, whereas simulation is pretending to be what one actually is not'. ${ }^{5}$ Bacon is critical of the calculated mis-representation of the self as being 'more culpable, and less politic' than secrecy or dissimulation; 'a general custom of simulation', he writes, 'is a vice, rising either of a natural falseness or fearfulness, or of a mind that hath some main faults, which .... man must needs disguise' 
(VI.20). If Othello's tales represent mere simulation, rather than accurate portraits of his life experiences, then what falseness, fearfulness, or faults might he be attempting to disguise?

In what follows, I will argue that much of what Othello says is fabricated or exaggerated through narrative simulation in order to maintain an exotic persona which guarantees his place within Venetian society. Contradictions in Othello's assertions expose a myth-making process by which, paradoxically, he overstates his foreign-ness in order to gain European admirers. In short, Othello does not fear being other; he fears not being other enough. Initially his simulations are a success, as he is 'oft invited' to dine at Brabantio's home (1.3.129), and promoted by public support to be commander of Cyprus. As the Duke admits, 'though we have there a substitute of most allowed sufficiency, yet opinion, a sovereign mistress of effects, throws a more safer voice on you' (224-6). Using travellers' tales and moving accounts of the 'battles, sieges, fortunes' that he passed (131-2), Othello markets himself to Venice as culturally exotic and militarily indispensable, qualities which are ultimately revealed to have been overstated.

\section{'Men Whose Heads / Do Grow Beneath Their Shoulders'}

For centuries, readers and playgoers have marvelled at Othello's irresistible fusion of poetry and bravery, as exemplified by his senate speech describing a lifetime of adventure:

I spake of most disastrous chances,

Of moving accidents by flood and field,

Of hair-breadth scapes i'th' imminent deadly breach ....

And of the Cannibals that each other eat,

The Anthropophagi, and men whose heads

Do grow beneath their shoulders. This to hear

Would Desdemona seriously incline.

Perhaps his most eloquent admirer (if no longer his most influential one) is A.C. Bradley, for whom Othello remains 'by far the most romantic figure among Shakespeare's heroes; and he is so partly from the strange life of war and adventure which he has lived from childhood. He does not belong to our world, and he seems to enter it we know not whence - almost as if from wonderland'. Bradley implies that audiences should accept Othello's claims that he actually saw his autobiographical marvels: 'this imagination, we feel, has accompanied his whole life. He has watched with a poet's eye the Arabian 
trees dropping their med'cinable gum, and the Indian throwing away his chance-found pearl; and has gazed in a fascinated dream at the Pontic sea rushing, never to return, to the Propontic and the Hellespont'; that Othello actually saw headless men. ${ }^{6}$

As T.W. Baldwin and Kenneth Muir have demonstrated, Shakespeare cribbed details from the senate speech (and others lines praised by Bradley) from Pliny the Elder's popular Historia Naturalis, a pioneering encyclopedia translated into English as The History of the World by Philemon Holland in 1601.7 The most notorious passages are found in Book VII which describes such anthropological wonders as nose-less Ethiopians, one-eyed Arimaspi, the Cinamolgi who have snouts like dogs, and various people who walk on their hands. ${ }^{8}$ Pliny was particularly fascinated by the Anthropophagi, a tribe whose members, he claimed, live at 'the North pole', adorn themselves with the scalps and hair of their victims, and drink out of human skulls (VII.73). Geographical consistency was never Pliny's strong point, and elsewhere his Anthropophagi are grouped with Ethiopian tribes such as the Blemmyi whose faces grow in their breasts - clearly Othello's men whose heads grow beneath their shoulders (V.52, VI.67).

Dismissed by modern scholars as a 'great miscellany of entertaining misinformation', Pliny's volumes were ransacked by Renaissance storytellers as a 'stock source of literary decoration'. ' That Shakespeare, who may not have travelled far beyond Stratford and London, should use Pliny to spice up his play seems poetic license. Such a practice would certainly be in keeping with Erasmus's recommended inclusion of Pliny's wonders - 'Scythians, cannibals, Indians, troglodytes, and so on' - as useful decorations in his influential manual of rhetoric, De Copia (c.1512). ${ }^{10}$ The playwright may also have appreciated similarities between his fictional general and the adventurous Roman encyclopedist who was likewise a military commander. ${ }^{11}$ Pliny was especially popular among armchair-travellers; Montaigne wrote that 'If any credit may be given unto Plinie or to Herodotus .... Some Countries there are, where men are borne headlesse, with eyes and mouthes in their breasts; where all are Hermaphrodites; where they creep on all foure' (II.xii.470). Montaigne cites the usual litany of wonders, but I find most interesting the essayist's skeptical prefatory 'if. As scholars such as Margaret T. Hodgen and Eldred D. Jones have documented, Pliny was cited uncritically for over a thousand years, that is until a new wave of empirically minded explorers returned home to Renaissance Europe with more sober eye-witness descriptions of the world. ${ }^{12}$ By Shakespeare's day, two versions of Africa - one legendary, the other revisionary - co-existed in the popular imagination. ${ }^{13}$ 
Discerning readers became less and less inclined to give 'any credit' to Pliny, such that Robert Burton devoted a chapter of his Anatomy of Melancholy (1621-52) to questioning reports of monsters and marvels, and stated categorically, 'I would censure all [of] Pliny's ... lies'. ${ }^{14}$

Playgoers, too, witnessed such stories being mocked and travellers being dismissed as charlatans in a wide range of plays. In Thomas Dekker's Patient Grissil (1603), one character recounts having seen 'people with heds like Dogs,' people 'without heads, hauing their eyes nose and mouths in their breasts', Pigmies no larger than toys, and one-legged people who can outrun a horse - but he is the aptly named buffoon, Babulo. ${ }^{15}$ In Richard Brome's The Antipodes (1638), a wealthy family enlists the help of a physician in order to cure their son Peregrine of his Mandevillian 'fits':

Pray, Doctor Hughball,
Play the man-midwife and deliver him
Of his huge tympany of news - of monsters,
Pygmies and giants, apes and elephants,
Griffins and crocodiles, men upon women,
And women upon men, the strangest doings. ${ }^{16}$

Eventually, Peregrine is purged through a kind of 'therapeutic performance' of the eponymous play, 'The Antipodes', in which he plays a wandering knight, armed with a wooden stage-sword, who trashes an 'enchanted castle' (the tiring house) in a hallucinatory encounter with puppets, monsters, Cyclops, and other 'jigambobs and trinkets' (3.3.297-313). The profusion of such examples suggests that in the early seventeenth century, stage travellers describing one-eyed monsters and hair-breadth 'scapes were more likely to be figures of scorn than wonder. ${ }^{17}$

In fact, well before Brome's satirical excoriation of travel fantasies, scoffing at Pliny's marvels had become a sign of education and sophistication. In The Tempest (1609) Gonzalo remarks that even 'boys' had become skeptical of the existence of 'men / Whose heads [stand] in their breasts'. ${ }^{18}$ Upon seeing Prospero's magic banquet, the ship-wrecked travellers' remark that no-one at home will believe they saw such a wondrous vision: 'GONZALO. If in Naples / I should report this now, would they believe me? / If I should say, I saw such islanders' (3.3.27-9). Prospero's island is unique in that, for once, the stories would be true; but the castaways know that, home in Europe, there exists a reflexive disbelief of travel narratives. This skepticism has been noted by modern scholars, but few since the eighteenth century have considered the implications of Othello asserting the veracity of, or Desdemona 'seriously' 
inclining to hear, such outlandish tales. ${ }^{19}$ If Naples should doubt Gonzalo, shouldn't Venice doubt Othello?

Regardless of whatever form of rhetorical amplification is recommended to authors in manuals like De Copia, in the context of the play itself Othello's incorporation of Pliny-esque tales and discredited legends into his life story radically undermines his credibility. Could Shakespeare be using Pliny to signal playgoers not to believe everything the general says? Until recently, the implications of Horace Howard Furness's incredulity on this subject went largely unexplored: if Shakespeare had ever read this chapter in Pliny, brimming over as it is with monstrosities, he would not have selected as a striking item in Othello's "trauels history" such a trifling distortion as a man with his face in his breast'. ${ }^{20}$ To my mind, locating the precise literary origins of such 'distortions' (as do source-hunters like Baldwin and Muir) is less germane than exploring the implications of their inclusion in the first place. Andrew Hadfield proposes that Othello deliberately forgets his first-hand knowledge of Africa in order to join the ranks of those with none: 'by identifying with European travellers against the bizarre races of his native Africa [and by] writing his own traveller's tale[,] he gives the Venetians exactly what they want to hear'. In other words, the self he fashions is 'elaborately constructed to suit the role of a European adventurer, and his [limited] access to knowledge'. According to the logic of this argument Othello's tales are forged in order to transform an 'erring' (ie wandering) Barbarian into an 'erring' (ie mistaking) European. ${ }^{21}$ Yet as I will demonstrate, at every turn Othello asserts the veracity of his tales: he is not pretending to be naive or foolish or credulous.

By suggesting that Othello lies, and wants the Europeans to believe his lies, my argument departs from Hadfield's view, as well as from Walter S.H. Lim's similar proposal that Othello seeks to 'obliterate his African self and become a 'tabula rasa' onto which he would 'inscribe all the values of Venetian culture'. ${ }^{22}$ Venice does not need another Venetian. It needs an exotic other to entertain its dinner guests and protect its borders, and Othello is only too happy to play up his heroic differences for their amusement and his own advancement. But proffering unsubstantiated stories as unassailable facts for personal gain is a dangerous business - as Sir Walter Ralegh discovered. After two unsuccessful voyages to Guiana and exaggerated claims of the wealth to be found there, both Elizabeth I and James I lost patience with his broken promises and stories, including his (now-notorious) report about the Ewaipanoma, 'a nation of people, whose heads appeare not above their shoulders; which though it may be thought a meere fable, yet for mine owne part I am 
resolved it is true, because every childe in the provinces of Arromaia and Canuri affirme the same'. ${ }^{23}$ James was eventually angered by Ralegh's failure to 'substantiate his own language with material proof,' and ordered his execution for lying. ${ }^{24}$

If by 1604 Shakespeare's contemporaries expected more balanced eyewitness accounts of faraway places and peoples, my point is not to blame a fictional character for failing to keep up with the latest developments in exploration and anthropology; instead, it is to highlight the likelihood that many early playgoers did. ${ }^{25}$ To contextualize Othello's pseudo-exoticism is to consider how audiences may have recoiled, less from the race, than from the words of a man who appears to be a braggart, a traveller, and a liar. Paradoxically, the harder Othello tries to be other, the more he becomes mundane; metamorphosing from an 'extravagant and wheeling stranger' into the man next-door - a domesticated husband who misses dinner engagements, quarrels with his wife, tells tall tales, and frets about horns on his head.

\section{'The Rites For Which I Love Him'}

When Iago reassures Roderigo that Desdemona's love for Othello will prove short-lived, the ancient predicts that she will soon weary of her older husband: 'will she love him still for prating? let not thy discreet heart think it. Her eye must be fed ... to inflame [the blood] and to give satiety a fresh appetite' (2.1.222-6). Iago's insinuation contains a grain of truth, only it is her ear, not her eye, that must be fed with stories of faraway places and feats of bravery. She admits:

to his honours and his valiant parts

Did I my soul and fortunes consecrate,

So that, dear lords, if I be left behind,

A moth of peace, and he go to the war,

The rites for which I love him are bereft me.

Although rites is often glossed as a risqué pun on the 'amorous rights' of the marriage bed, in the context of her loving his tales of 'valiant' deeds the term may also to denote the ritual of storytelling itself. ${ }^{26}$ By Shakespeare's day, telling marvelous tales had become a ritualized performance evinced by 'the persistence of traditional descriptive cultural formulae' (such as the phrase 'men whose heads grow in their breasts' and its variants), a performance 'any Elizabethan Englishman would have been expected to do, in exchange for his supper, on his return from faraway places'. ${ }^{27}$ Desdemona's enthusiasm for this 
custom is hardly unique; Louis B. Wright notes that tales of exploration and adventure 'touched the imaginations of Renaissance Englishmen [sic] like a heady drug .... There was created an appetite, insatiable and increasing, for accounts of the strange new worlds'. ${ }^{28}$ Iago's skepticism about Othello's 'bragging' is hardly unique either. Wright prefaces his survey of travel literature with Barnabe Rich's caution: 'Travellers are priuileged to lie, and at their returne, if they doe hitte into a company that neuer trauelled towards the South Pole, beyond Gads hill, you shall heare them speake of wonders' ${ }^{29}$

That tales were embellished for credulous listeners was less disturbing than the fact that, as another contemporary complained, ambitious raconteurs 'of base descent and lineage' could use tales to achieve unwarranted social prominence: '[They] haue thereby not only bin commended to the Honourable; but also their owne experience and triall of occurents in trauelling, doth procure thus much more than ordinary vnto them' ${ }^{30}$ Marlowe's Edward II (c.1592) evokes this process when Gaveston invites a traveller to audition for his coterie of favorites, 'To wait at my trencher and tell me lies at dinnertime, / And as I like your discoursing, I'll have you'. ${ }^{31}$ What if, analogously, Othello told lies at dinnertime, Desdemona liked his discoursing, and had him? Upon learning that a North African has parlayed exotic stories into a secret marriage to this local heiress, the Duke comments, 'I think this tale would win my daughter too', not so much confirming the veracity of Othello's story, as acknowledging its impact on less worldly Venetians (1.3.172). The line compliments Othello for his narrative prowess, but warns other citizens (and their daughters) not to be similarly taken in.

Hence the critical commonplace that Othello employs narrative self-fashioning to win Venice's admiration and Desdemona's heart (both city and bride, in effect, 'loved [him] for the dangers [he] had pass'd' [1.3.168]). ${ }^{32}$ His rise to prominence among European civilians and soldiers stem in part from his undisputed bravery in wartime, but in larger part from his storytelling in peacetime. Lodovico's description of an enraged Othello evokes a carefully crafted public image based on acts of past heroism: 'Is this the noble Moor whom our full senate / Call all in all sufficient? This the nature / Whom passion could not shake' (4.1.264-6). Like a spin-doctoring modern politician, Othello's reputation is maintained using a patchwork of slogans: 'The Noble Moor,' 'The Nature Whom Passion Could Not Shake'. Others assist in his myth-making process. When asked if the general has 'wived', Iago characterizes the elopement as a daring act of piracy, 'he tonight hath boarded a land carrack: / If it prove lawful prize, he's made for ever' (1.2.50-1). Elsewhere Cassio waxes poetical about how Othello 'achieved' a maid that 
'paragons description' and 'in th' essential vesture of creation / Does tire the inginer' (2.1.60-4). When they land in Cyprus, Cassio, Desdemona and Iago pass the time on shore telling jokes; but upon his arrival, Othello glamourizes the perillous crossing: 'May the winds blow till they have wakened death, / And let the labouring bark climb hills of seas, / Olympus-high, and duck down again as low / As hell's from heaven' (184-7). Even a shared ordeal is presented as having been somehow more arduous for the storied commander of the fort.

However, to invoke commonplaces articulated by another consummate politician, Ulysses (in Troilus and Cressida, c.1602-3), 'no man is the lord of anything, / Though in and of him there be much consisting, / Till he communicate his parts to others'. ${ }^{33}$ Initially Othello proves to be one of Ulysses's great 'communicators' -entrancing auditors with self-promotional speeches that prompted Samuel Johnson to praise the 'fiery openness of Othello, magnanimous, artless, and credulous, boundless in his confidence' ${ }^{34}$ However, following the unforseen destruction of the Turkish fleet en route to Cyprus, Othello cannot continue to fulfil high expectations of glory. 'Perseverance,' continues Ulysses, 'Keeps honour bright: to have done is to hang / Quite out of fashion, like a rusty mail / In monumental mockery' (Tro 3.3.150-3). In Cyprus, Othello can assert his greatness verbally, but not demonstrate it physically. His 'boundless' confidence erodes as he cannot replenish the store of novelties that feeds auditors who, like Desdemona, 'with a greedy ear / Devour up [his] discourse' (1.3.150-1).

The significance of such a setback for a chronic storyteller cannot be overstated, for as George Puttenham warns aspiring orators in his Arte of English Poesie (1589), 'all old things soon wax stale and loathsome, and the new devices are ever dainty and delicate'. ${ }^{35}$ Such an idea is confirmed in Erasmus's praise of rhetorical variety in De Copia: 'Just as the eyes fasten themselves on some new spectacle, so the mind is always looking round for some fresh object of interest. If it is offered a monotonous succession of similarities, it very soon wearies and turns its attention elsewhere'. ${ }^{36}$ Iago's imputations of cuckoldry will raise the stakes for Othello considerably, from a concern for providing rhetorical variety that enables Desdemona's vicarious adventures, to an encroaching fear that 'old' and 'stale' marvels will prompt her to seek literal (ie sexual) adventures elsewhere: 'O curse of marriage / That we can call these delicate creatures ours / And not their appetites!' (3.3.272-4). Othello finds himself in an impossible situation, straining to maintain a stable identity built on a shifting foundation of rhetorical novelty. As his assertions become increasingly implausible, one wonders what, if 
anything, constitutes the core of this 'storied self..$^{37}$ Janet Adelman has argued that 'Othello is everywhere associated with the kind of interior solidity and wholeness that stands as a reproach to Iago's interior emptiness and fragmentation'. ${ }^{38}$ Yet I believe that rather than creating a 'split' in Othello's self, Iago's racism and prurience expose fissures that were already present from the beginning, as evinced by the general's reliance on simulation.

\section{'My Travailous History'}

Othello describes his his autobiographical narrative as a 'travailous history' (1.3.140), a phrase which has occasioned some editorial controversy; for its precise spelling either buttresses or undermines the verisimilitude of the tale itself. The 1622 Quarto reads 'trauells,' which sounds fairly neutral; but the 1623 Folio reads 'Trauellours,' suggesting a much closer relation to that popular genre, the traveller's tale. ${ }^{39}$ Broadly defined as 'literature of fantasy purporting to be fact', traveller's tales are accounts of phenomena that occur at such a remote distance from the lived experience of the auditors as to fascinate and entertain. ${ }^{40}$ In perhaps the most erudite example of the genre, Thomas More's Utopia (1516), the very name of its worldly narrator exposes the enterprise as a hoax: Raphael Hythlodaeus, teller of tall tales, 'learned in nonsense'. ${ }^{41}$ Peter Womack uses Othello's speech to illustrate his introduction to this genre, noting that 'The traveller's tale is a repeatable performance; it is as the exponent of a distinctive kind of talk that Othello acquires his dramatic substance and allure'. ${ }^{42}$ Womack outlines characteristics of traveller's tales: they spoke of strange, foreign, magic or wondrous creatures and customs; they appealed to vulgar and uneducated; they showcased the suffering of the teller as either pilgrim or victim; and they contained 'truth claims' that were essentially unverifiable: 'Precisely because the traveller has been so far away, his story is uncheckable .... the Anthropophagi and the misplaced heads are bywords for the implausibility of travellers' tales' (148). Since it was proverbial that travellers are liars, then those that believe them must be dupes. Perhaps to distance Othello and Desdemona from these associations, the Arden 3 editor emends the word to 'travailous' and glosses this (in my view improbable) French interpolation as 'toilsome, wearisome'. To Honigmann, Othello's is a sad tale, not a traveller's tale. ${ }^{43}$

By citing Othello's senate speech as an exemplary traveller's tale, Womack alerts us to the suspicious nature of subsequent marvellous truth-claims in the play. To be sure, some are not made in earnest. Othello calls his wife a 'fair warrior' (2.1.180), when she is less a soldier than a senator's daughter on her 
inaugural foreign adventure. He boasts of her musical talents, 'she will sing the savageness out of a bear' (4.1.186), though this comment becomes ominous when the Willow Song fails to preserve her or Emilia (at 5.2.246) from murderous husbands. Finally, when Desdemona cries after being slapped, Othello garbles the proverbial expression and intimates that 'each drop she falls' could sprout a live crocodile (4.1.244-5). These minor boasts may seem inconsequential, but taken together they form a pattern in which Othello assigns marvellous attributes to mundane events: here Desdemona's travelling, singing, and crying.

No truth-claims are more deadly serious than those surrounding the lost handkerchief. Many fruitful inquiries have uncovered contexts for this love token, ranging from the allegorical to the narratological to the anthropological. ${ }^{44}$ Most commentators seem prepared to take Othello at his word, that it was designed for Othello's mother, composed of silk spun by hallowed worms, dyed with mummy 'Conserved of maiden's hearts', decorated with strawberries sewn by a Sibyl, and given by an 'Egyptian charmer' to Othello's mother to 'subdue [his] father / Entirely to her love' (3.4.58-77). After all, as mentioned in my introduction, Othello insists that the story is 'Most veritable' (3.4.78). Yet the devil is in the details. He claims that the Sibyl was two-hundred years old. How is this possible? He claims that the dye was made of mummy, without specifying whether it was applied to the cloth (which should be white), or to the embroidered strawberries (which should be red). The Oxford English Dictionary states that 'mummy' denotes the colour brown, and Virginia Mason Vaughan cites research suggesting that it may actually have been black. How is either possible? Othello later claims that it was 'an antique token / My father gave my mother' (5.2.214-15). Can Othello's mother's made-to-order handkerchief also be Othello's father's 'antique' family heirloom? Can the sibyl of version one and the father of version two give the same gift? As Eldred Jones wonders, 'Are we to believe at all that this story of the handkerchief is true?' 45

Both stories cannot be 'most veritable,' but attempting to determine which one is so (some critics prefer version two) implicates the modern investigator as one more beguiled auditor of Othello's simulated tales. ${ }^{46}$ The sacred handkerchief recalls the curios, talismans, and oddities assembled in that early modern phenomenon known as the wonder cabinet. Steven Mullaney cites a 1599 account of a collector who displayed, among other marvels, 'an African charm made of teeth', 'a felt cloak from Arabia', 'a unicorn's tale', and 'a flying rhinoceros'. Such objects held a strange fascination for Shakespeare's contemporaries, and the jumbled disorder of the wonder cabinet itself represented a 
space in which the real and the fantastic, the sacred and the profane, could commingle: 'This was a room of wonder, not of inquiry'. ${ }^{47}$ The individual items in a curio collection function like the details of a traveller's tale: 'These are things on holiday, randomly juxtaposed and displaced from any proper context; the room they inhabit acts as a liberty or sanctuary for ambiguous things, a kind of half-way house for transitional objects' (42). As with the magical provenance of Desdemona's handkerchief, it doesn't much matter whether the Indian monkey-tooth charm really works; its functions in the cabinet are less to cure or further scientific knowledge than to entertain and satisfy the Elizabethan 'pleasures of the strange' or 'cultivation of wonder' (43). Likewise, when in 1550 the citizens of Rouen constructed a replica Brazilian village to impress their king, there was no pretense that it was an actual Brazilian village; this 'rehearsal of cultures,' as Mullaney terms it, 'embod[ies] a form of license, a suspension of customary limits, taboos, and other modes of cultural definition, that can only be temporary, a thing of passage' $(45,59)$.

Therefore it seems harmless enough that Desdemona should cherish her handkerchief and confide in it as a modern child might use a teddy-bear: 'she so loves the token', observes Emilia; 'she reserves it evermore about her / To kiss and talk to' (3.3.297-300). When Othello makes high-stakes truthclaims about its actual and abiding properties, however, he violates the spirit of marvellous collectibles. His insistence on the charm's literal truth causes its sentimental value to dissipate: 'is't true?' she asks; 'Then would to God that I had never seen't!' (3.4.77-9). By protesting too much, Othello transforms a harmless lie into a much more damaging one; for as Bacon observes in his essay 'Of Truth', 'it is not the lie that passeth through the mind, but the lie that sinketh in and settleth in it, that doth the hurt' (I.6). That Othello has regaled Desdemona's family with exotic lies that should pass through the mind, but instead sank in, is suggested by Brabantio's repeated claim that the Moor 'enchanted' his daughter with 'foul charms' (1.2.63-79; cf. 1.3.61-2). Othello laughs off these charges, countering that telling a story constitutes '[the] only ...witchcraft I have used' (1.3.170). Yet Othello cannot have it both ways: he cannot deny the use (or the existence?) of charms in one scene, then insist elsewhere that they are inextricably woven into the fabric of his love and family heirloom.

To her credit, Desdemona realizes that Othello is fabricating details for effect; she says, after hearing version one of the handkerchief story, 'This is a trick to put me from my suit' (ie on behalf of Cassio; 3.4.89). In his essay 'Of Lyers,' Montaigne confesses to having played a little 'trick' of his own on some 
friends to test the reliability of report (I.ix.24-9). After asking them to recall details of a shared experience, Montaigne reports finding that they 'recoile their narration so farre-backe, and stuff-it with so many vaine circumstances, that if the story bee good, they smoother the goodnesse of it' (I.ix.25). In other words, at each retelling they embellished, invented and 'bastardized' (as Montaigne phrases it) or 'simulated' (as Bacon might term it) details to the point of rendering the original tale unrecognizable. From this experiment, Montaigne determines that 'he who hath not a good and readie memorie, should never meddle with telling of lies' (I.ix.26, italics in original). Repetitions that generate contradictions expose the teller's lack of credibility; but contradictions can reveal much else besides: 'When they disguise or change, if they be often put to the repetition of one thing, it is hard for them to keepe still in one path, and very strange if they lose not themselves ... [for they] therein can have no such footing, or setled fastnesse'(I.ix.26). Montaigne suggests that shifting details reveal inconsistencies in the storied self of the teller; conversely, a consistent self-narration evinces a solid identity and communicates this to observers. Desdemona's approval of Othello's stories provides the secure footing or 'setled fastnesse' he craves. Roderigo marvels that she should '[tie] her duty, beauty, wit and fortunes' to such an unstable berth (1.1.133), but it is she that provides a safe haven where the 'wheeling stranger' can at last anchor his identity.

When Iago starts to pick away at Othello's confidence in this relationship (did Cassio go between you very oft?, indeed?, is he honest?), the ancient initiates a kind of cross-examination that Othello, unaccustomed to such verbal scrutiny, finds intolerable: 'By heaven, thou echo'st me / As if there were some monster in thy thought' (3.3.109-10). Suddenly, the man who regaled Venice with tales of cannibals and monstrous men finds himself confronted with an equally frightening tale told by a man who has travelled in the unfamiliar terrain of European society: 'O beware, my lord, of jealousy! / It is the green-eyed monster, which doth mock / The meat it feeds on' (3.3.167-9). Iago's account of how he lay waking while Cassio dreamed of making love to Desdemona (3.3.416-28) proves as unverifiable as any traveller's tale; yet to the uninitiated, it is devastatingly persuasive:

OTHELLO. O monstrous, monstrous!

IAGO. Nay, this was but his dream.

For Othello, Iago's insinuations form cautionary tales about Venetian witches who seal up their fathers' eyes 'close as oak' (213-14), and insatiable wives who 
bed paramours like 'goats, as hot as monkeys' (406). Ignorance of these marvels exposed him to unforseen dangers, and implicated him in a humiliating tale, that of the 'cunning whore of Venice / That married with Othello' (4.2.91-2). Now that he has been apprized of their 'country disposition,' namely, that 'In Venice [women] do let God see the pranks / They dare not show their husbands' (3.3.204-6), Othello recasts a personal revenge-killing as a selfless act of civic heroism: 'she must die, else she'll betray more men' (5.2.6).

Iago insinuates himself into Othello's trust precisely because the ancient adopts his superior officer's penchant for telling strange tales. Whereas Othello specializes in African exoticism, Iago trains his pseudo-anthropological sights on the strange customs of Europe, such as in his warning to Othello of a veritable pandemic of cuckoldry: 'There's millions now alive / That nightly lie in those unproper beds' (4.1.67-8). No evidence is provided other than the credibility of the observer who 'know [s his] country disposition well' (3.3.204). Right from his first appearance Iago provides insider information concerning the improbable, such as in his warning to Brabantio that the latter's daughter is 'making the beast with two backs' with Othello: 'you'll have your daughter covered with a Barbary horse; you'll have nephews neigh to you' (1.1.109-15). Pliny reports that 'certain Indians engender with beasts, of which generation are bred certain monstrous mongrels, half beasts and half men', and cites as an example 'men with heads like dogs, clad all over with the skins of wild beasts, who in lieu of speech used to bark' (VII.79, 76-7). As with Iago's millions of cuckolded Europeans, Pliny claims that the population of these dog-men is 'known' to be 'above 120,000 in number' (77). Will Brabantio also have four-legged grandchildren? It seems inconsistent, even hypocritical, to celebrate Othello's tale of headless Africans, but recoil from Iago's image of bestial coupling and Pliny's account of 'mongrel' children. Playgoers may not have made such distinctions. Iago also takes a page out of Pliny's tribal summaries by describing the drinking habits of various nations: 'Your Dane, your German, and your swag-bellied Hollander - drink, ho! - are nothing to your English .... Why, he drinks you with facility your Dane dead drunk; he sweats not to overthrow your Almain; he gives your Hollander a vomit ere the next pottle can be filled' (2.3.73-80). Just as Othello gives his tales an aura of truth by making them part of his autobiography, here Iago asserts eye-witness credibility: 'I learned it in England' (72). And just as Desdemona is enraptured against 'her better judgment' (3.3.240) by Othello's African adventures, Cassio likewise agrees, against his own better judgment, to carouse to the general's health. The irony of Iago's story is that, 
as any playgoer who recently saw Shakespeare's company perform Hamlet already knew, the Danes were Europe's undisputed drinking champions. ${ }^{48}$

Traveller's tales are superficially convincing because, as readers of Herodotus, Pliny or Mandeville can attest, the tellers heap up circumstantial details that add an aura of verisimilitude to their fantastic accounts. For example, Pliny notes that the dog-men of India prefer to live on hills, where they have adapted 'sharp and trenchant nails' in order to chase fowl (VII.77). If readers doubt the main contention (eg the existence of dog-men), the accompanying details make superficial sense (eg sharp nails would be good for footing on steep slopes, as well as for seizing prey). That the Sciopodes have only one large foot sounds incredible, until Pliny clarifies their function in the searing Indian summer: 'they lie along on their back, and defend themselves against the sun's heat with their feet' (77). Most of Pliny's anecdotes contain three basic ingredients: marvel, detail, and source; for example, Pygmies are only 'three times nine inches high' (marvel), which causes them to be 'troubled' by marauding cranes (detail), as 'Homer ... hath reported' (source) (78). Yet such stories do not bear close scrutiny (eg why grow a giant foot for shade, when a hut or leafy tree would be just as cool? why eat crane eggs if gathering them is dangerous and other food is abundant?). The very surfeit of details that prop stories up can cause them to collapse beneath the burden of consistency and logic. Thomas Rymer points out that the profusion of details itself should alert listeners that the teller is fabricating a tall tale. The critic illustrates his point with a parody of the exotic cant in Othello's senate speech: 'Nodes, Cataracts, Tumours, Chilblains, Carnosity, Shankers, or any Cant in the Bill of an High-German Doctor is as good fustian Circumstance, and as likely to charm a Senators Daughter'. To Rymer, that Desdemona should fall for such nonsense suggests that this 'supersubtle' Venetian is no more sophisticated than a 'Countrey Chamber-maid'. ${ }^{4}$

When Othello's exotic details change or contradict one another, that few stage characters question their veracity does not mean that early audiences accepted them unquestioningly. Surely Rymer was not alone in his objections to Othello's fustian circumstances and Desdemona's credulity: 'Nothing is more odious in Nature than an improbable lye; And certainly never was any Play fraught like this of Othello with improbabilities'. ${ }^{50}$ Shakespeare deliberately peppers Othello's assertions with errors to underscore their essentially simulative nature. Editorial emendations that 'rectify' these slips create the erroneous impression that they stem from errors on Shakespeare's part, or on the part of his compositors, printers, and so forth. In the process, Othello's tales gain unwarranted credibility. For example, when in his final moments 
he reaches for a hidden weapon, 'a sword of Spain, the ice-brook's temper' (5.2.251), Ridley, Sanders and Honigmann emend the quarto's 'Isebrookes' (ie Innsbruck's) to 'ice-brook's' and heap up circumstantial details (and cite classical authorities) about how Toledo blades were forged and then cooled in mountain streams fed by melting snow. ${ }^{51}$ Yet I propose that here, typically, Othello does some narrative forging of his own, borrowing associations from two weapon-centres whose precise geographical locations are little fuzzy in his mind, in order to invent a marvelous provenance for his über-sword. It is no coincidence that the only other character on-stage here is Desdemona, lifeless in her bed. Even in death, Othello concocts tales to impress her.

\section{'Forwards To Tell Stories'}

In his essay 'Of Travel' (cited in my epigraph), Bacon admonishes the novice traveller not to embellish his tales upon returning home, but to 'be rather advised in his answers, than forwards [ie eager] to tell stories' (XVIII.58). Despite being descended 'From men of royal siege' (1.2.22), Othello fails to secure a place among Venice's power elite, not because of his race, but because he is so incessantly forwards; as Castiglione's Sir Frederick might say, 'in his communicatyon ... [he is not] alwayes heedefull not to goe out of the lykelyhoode of truth ... as manye doe, that never speake but of wonders, and will be of suche authoritye, that everye uncredyble matter must be beleaved at their mouth'. On this point Sir Frederick sounds remarkably like Iago, critical of Othello's fantastical lies: 'Oure Courtier ...shall be no carier about of trifling newes .... He shall be no babbler, not geven to lyghtenesse, no lyar, no boaster, nor fonde flatterer, but sober, and keapinge hym alwayes within his boundes' ${ }^{52}$ When prompted by emotions, Othello lapses into even greater rhetorical excess, such as when he transforms his wife's perceived adultery into a cosmic event: 'Heaven stops the nose at it, and the moon winks, / The bawdy wind that kisses all it meets / Is hushed within the hollow mine of earth' (4.2.78-80). In his final moments Othello tries valiantly to keep within bounds - 'No more of that ... Speak of me I am' (5.2.338-40) - but he cannot refrain from translating mediocrity into marvels.

When Gratiano bursts into the death chamber in the final scene, Othello instinctively launches into a story designed to intimidate his opponent. 'Behold I have a weapon', he blusters; 'with this little arm and this good sword / I have made my way through more impediments / Than twenty times your stop' (5.2.257-62). However, this pre-emptive verbal strike fizzles as quickly as it began - 'but, O vain boast' (262) - because Othello has nothing left to 
fight for, no reason left to live. Emilia may already have sensed his decline, when moments earlier she braved a similar bluffing menace, 'I care not for thy sword' (161). Venice will charge him with murder, view him with contempt, but most intolerably, no longer admire his fantastic stories. Lodovico deflates his bluster in one trenchant line clarifying Othello's new status in the Europeans' eyes:

OTHELLO. Whip me, ye devils,

From the possession of this heavenly sight!

Blow me about in winds, roast me in sulphur,

Wash me in steep-down gulfs of liquid fire ....

LODOVICO. Where is this rash and most unfortunate man?

OTHELLO. That's he that was Othello? here I am.

The 'he that was Othello' was the legendary general and the storied traveller now demoted to the status of 'rash and unfortunate man', so breathtakingly ordinary.

It was Othello's extraordinary reputation, more than his actual abilities, that once inspired confidence in the troops under his command. When the Turkish menace disappears, Othello's tales become more outlandish, and his insistence on their veracity more strident. In The Prince (1532), Niccolo Machiavelli points out that 'nothing gaines a Prince such repute, as great exployts, and rare trialls of himselfe in Heroicke actions'.$^{53}$ The author cites as an example Ferdinand II of Aragon (1452-1516), who overcame initial political weaknesses to become the first great king of Christendom, invading Africa and attacking France 'under the same cloke [ie of religion] .... and so alwaies proceeded on forwards contriving of great matters: which alwayes have held his subjects minds in peace and admiration' (84). A shrewd prince keeps his subjects in check by ensuring, through continual warfare, that they never have 'leysure ...so to rest, as that they might ever plot any thing against them' (84). Once the Turkish fleet is dispersed, Iago's plotting certainly intensifies. And once Othello's reputation is marred by imputations of cuckoldry, and his lieutenant is promoted to govern the island, what will Othello use to keep Venice in awe? Asserting his authority through 'great matters' no longer seem possible, so Othello must invent new ones, likening his suicide to a second act of civic heroism:

say besides that in Aleppo once,

Where a malignant and a turbanned Turk

Beat a Venetian and traduced the state, 
I took by th' throat the circumcised dog

And smote him - thus! [He stabs himself.]

His introductory phrase 'say besides' makes the account sound more like a future supposition (eg 'Let us say [suppose] a Turk attacked a Venetian, here is how I would respond ...') than a command to relate an actual past event. No matter how malignant the threat may once have been - and typically we have no eye-witness to corroborate Othello's story - his present response to the Turkish menace can only be hypothetical. Attempts to sort out such details as whether his final speech refers to a 'base Indian' throwing away a pearl (a common sixteenth-century traveller's tale, according to Sanders) or a 'base Judean' (a multivalent allusion to Judas and Christ, or Herod and Mariam), seem to miss the point. ${ }^{54}$ The garbling of the text mirrors the garbling of Othello's stories; neither emendation can be 'true' because the tale is simulated.

In his influential discussion of the play, Stephen Greenblatt observes that Iago and Othello both employ 'improvisation' (a concept similar to Bacon's simulation) to define their selves to, and assert their power over, others. Yet the process is provisionary and contingent, as the improviser's 'identity depends upon a constant performance ... of his "story," a loss of his own origins [and] an embrace and perpetual reiteration of the norms of another culture'. If identity, like culture, is maintained through narrative, then Iago proves that these foundations can be 'unfashioned, refashioned, inscribed anew in a different narrative'. Greenblatt argues that Iago forges a radical revision of Othello's identity, from assimilated hero to monstrous cuckold. ${ }^{55}$ I would counter that the assimilation occurs precisely when Othello ceases to be other and becomes a naturalized European cuckold. James Calderwood also explores how Othello 'must continually re-establish his sense of self narratively,' and that the fusion of self and story renders Othello vulnerable to hostile questions and counter-narratives - processes the critic likens to 'put[ting] his language on the rack'. ${ }^{56}$ Calderwood supports this analogy by citing Othello's epileptic descent into incoherent prose:

Lie with her? lie on her? We say lie on her when they belie her! Lie with her, zounds, that's fulsome! - Handkerchief! confessions! handkerchief!-To confess, and be hanged for his labour! First to be hanged, and then to confess: I tremble at it .... Pish! Noses, ears, and lips. Is't possible? Confess! handkerchief! O devil!

(4.1.35-43, emphasis added)

In this Othello's most rhetorically unguarded moment, I believe we catch a glimpse of the primordial narrative chaos deep inside his mind. What we see 
is the process by which lived experiences (the lost handkerchief) combine with imagined terrors ('O devil!') to produce a story (or at least, the very rough draft of a story) featuring the sexual proclivities of Venetian wives, a man who confesses after being hanged, and looming faces with noses (cut off and 'thrown' to dogs as per 4.1.141-2?), ears ('greedy' devouring ones, as per 1.3.150-1?), and lips ('thick' ones, as per the racist epithet used at 1.1.65?). Is't possible? In a traveller's tale, anything is possible: undifferentiated promiscuity, the speaking undead, horrible disfigurements. Among the delirium of marvels that constitutes Pliny's seventh book we find Hermaphrodites who enjoy auto-erotic 'carnal knowledge, one of another interchangeably by turns', people who can resuscitate victims of poison, sorcerers who can kill with their eyes, Indians who live to 200 years, and facial deformities such as 'people born with eyes like owls' (VII.72-4). When in control, Othello used such oddities to spice up his life story; now, they are fatally encroaching on his ability to discern fact from fiction, plausibility from utter improbability.

If, as Calderwood asserts, for Othello 'honest is a transcendental signifier that stabilizes discourse', then the mistaken belief that Desdemona is false occasions such extreme discursive turmoil that the hidden processes by which Othello constitutes his storied self are laid bare. ${ }^{57}$ When he loves her not, narrative chaos 'is come again' (3.3.91-2). In 'Of Lyars,' Montaigne outlines the perils of fashioning stories, of simulating the self to please different auditors:

I have often ... seene the experience, at the cost of those, who professe never to frame their speech, but as best shall fit the affaires they negotiate, and as best shall please the great men they speake unto ...whence it followeth that of one selfe-same subject they speak diversly, as now yellow, now gray, to one man thus, and thus to another. And if peradventure these kind of men hoard-up their so contrarie instructions, what becomes of this goodly art? (I.ix.26-7).

Once disordered, Othello's handkerchief becomes now a gift from a Sibyl, now from his father; his sword now Spanish, now Austrian; the pearl thrown by a Judean, or was it by an Indian?; and so forth. Othello does not anticipate listeners 'hoarding up' such details and sifting them for contradictions; but many do, as playgoers and readers have long puzzled at his narrative inconsistencies. Not to question his purported feats would be to exhibit credulity unbefitting even a schoolboy; as Montaigne points out, 'there is no scholler so meanely learned, but will convince [Pliny] of lying, and read a lecture of contradiction against him'. ${ }^{58}$ 
Iago had earlier assured Othello that, of the 'millions now alive' that lie in beds tainted by cuckoldry, his 'case [was] better' (4.1.67-9). This is perhaps the play's most devastating lie, for Othello's case actually proves much worse. He is the 'gull', the 'dolt, / As ignorant as dirt' (5.2.159-60), who espoused outlandish tales yet is duped by the most mundane European legend of all. Othello kills his bride because of Iago's tale of a European tribe of 'civil monster[s]' with horns upon their foreheads (4.1.64), and because he cannot abide joining them, becoming a 'fixed figure for the time of scorn / To point his slow and moving finger at' (4.2.55-6). Early playgoers may have sympathized with his fear of, but not with his disproportionate response to, the prospect of horned humiliation. Montaigne cynically writes that tales of cuckolded husbands are 'not strange', but actually rather commonplace; Pliny's account of a king who dreamed of a bull-baiting and awoke to find actual horns on his head - now that, writes the urbane Frenchman, is a truly 'memorable' story. ${ }^{59}$ Desdemona dies in vain; for even if she were unfaithful, Othello's humiliation would eventually be replaced in the neophillic popular imagination by some new marvel.

Reading Othello in light of the period's sophisticated rejection of Plinyesque tales, and the drama's derision of an emerging comic butt, the stagetraveller, may help temper the anachronistic romanticization of the play's tragic protagonist. I suggest that the play underscores the unreliability of eye-witness accounts of strange events, a thematic commonplace in Othello criticism, to be sure, but one that has received less attention than it merits in the context of traveller's tales. ${ }^{60}$ In the source's eavesdropping scene, Cinthio's Moor observes his Ensign and Disdemona's supposed paramour speak, but cannot hear what they say: 'chatting of quite other matters than the Lady, he [ie the Ensign] laughed heartily and, displaying great surprise, he moved his head about and gestured with his hands, acting as if he were listening to marvels' (379, emphasis added). This phrase provides Shakespeare with a motif that would become central in Othello, namely, the use of apparent marvels to deceive. In the play's rendering of this scene, Iago positions Othello as if to observe the landscape and inhabitant of a foreign land:

Do but encave yourself

And mark the fleers, the gibes and notable scorns

That dwell in every region of his [ie Cassio's] face;

For I will make him tell the tale anew

Where, how, how oft, how long ago, and when

He hath and is again to cope your wife. 
From his secret 'cave', Othello proceeds to misconstrue Cassio's verbal account of how Bianca accosted him in the street, as physical gestures indicating a 'Roman ... triumph' (128). Out of earshot, the pantomime appears to be a grotesque ritual, with participants hanging, lolling, weeping, shaking, and pulling (136-9). The only thing to be truthfully discerned in the 'region' of Cassio's face is gossippy laughter; the only wildlife present is the 'monkey' and 'fitchew' he affectionately terms his mistress $(128,145)$. By dramatizing the process by which Othello witnesses a strange spectacle and drastically misinterprets what he sees, the play undermines his credibility as a witness to other marvels. In the collision of cultures, one cannot always trust eyewitness accounts; and even first-hand 'ocular proof can be deceptive.

If for Shakespeare's contemporaries it had become commonplace that travellers lied, the dangers of accusing soldiers of the same proclivity were also widely acknowledged. The exchange that opens act 3 scene 4 might seem like minor quibbling -

DESDEMONA. Do you know, sirrah, where lieutenant Cassio lies?

CLOWN. I dare not say he lies anywhere.

DESDEMONA. Why, man?

CLOWN. He's a soldier, and for me to say a soldier lies, 'tis stabbing (1-6)

- but its placement on the heels of Othello's resolution to find 'swift means of death' for both his wife and lieutenant (3.3.480) underscores the seriousness of the issue, as well as the essential incompatibility of the two roles Othello has adopted. For Othello the traveller, his far-fetched stories are indulged, their incongruities tolerated; but for Othello the soldier, his verbal excesses like blustering epithets (1.1.13), prattling (2.1.205), or bragging (2.1.221) are eroding his credibility, and with that his ability to command respect. Finally, for Othello the commander of Cyprus, his increasingly bizarre behavior prompts onlookers like Lodovico to wonder aloud 'Are his wits safe? Is he not light of brain?' (4.1.269). Lodovico wisely waits until Othello is out of earshot to make this observation, but the latter's discovery that he has indeed lost credibility, perhaps at the devastating moment he is 'command[ed] ... home' by the letter Lodovico's brings (4.1.235), and the frenzy of stabbings that closes the play, confirm the prophetic seriousness of the clown's evasions: 'I know not where he [ie Cassio] lodges, and for me to devise a lodging and say he lies here, or he lies there, were to lie in mine own throat' (3.4.11-13). To 'devise' (invent, simulate) is to lie, is to give oneself the lie, is to stab oneself in response to the lie. It is worth noting that the earliest extant response to a performance of Othello, the notebook of Edward Pudsey (d. 1613), cites this passage almost 
verbatim; the dangers associated with lying and soldiers made a strong impression on at least one early-modern playgoer. ${ }^{61}$

Lies may be indispensable for Machiavelli's prince and the stock in trade of the story-telling traveller, but they must not be uttered by a military man of honour. Othello is all three, but he is a soldier first, and cannot live with the contradictions. When interrogating Iago about the street brawl in Cyprus, Montano reminds the assembled garrison, '[If thou] dost deliver more or less than truth / Thou art no soldier' (2.3.215-16). Bacon confirms the sentiment in 'Of Truth,' where he writes 'There is no vice that doth so cover a man with shame as to be found false and perfidious' - though he qualifies the observation (I.7). One must not be found false, but Othello eventually is; as Gratiano observes, 'All that's spoke is marred' (5.2.355). Othello's suicide functions as much to end his life, as to put an end to the stories of his life. Yet this, too, is doomed to fail. Earlier Lodovico had wondered at Othello's striking of Desdemona, 'this would not be believed in Venice / Though I should swear I saw't' (4.1.241-2). Now Lodovico can relate Othello's 'heavy act' to the listeners back home - one last traveller's tale, but with a difference. This time there are bodies, bloodstains, and witnesses to corroborate his fantastic tale.

\section{Notes}

Portions of this paper were presented at the conference, 'The Mysterious and the Foreign in Early Modern Culture,' at McMaster University (October 4-5, 2002). The author gratefully acknowledges the input of his fellow conference participants, the editorial suggestions of Helen Ostovich and the anonymous readers at Early Theatre, and financial support provided by the Niagara University Research Council and the Dean of the College of Arts and Sciences.

1 Bacon, 'Of Travel', The Essays of Francis Bacon, ed Clark Sutherland Northup (Boston, 1936), XVIII.56-8, quotation on 58. Hereafter cited parenthetically by chapter / page number.

2 Cinthio's tale, translated by Geoffrey Bullough, is reproduced in Appendix 3 of Othello, ed E.A.J. Honigmann, Arden 3 Shakespeare (Walton-on-Thames, 1997), 368-87, quotation on 371. References from Othello and Cinthio are from this edition and will be cited parenthetically (with Honigmann's editorial italics omitted). 
3 Montaigne, 'Of Giving the Lie', The Essayes of Montaigne, trans John Florio, 1603; ed J.I.M. Stewart (New York, 1933), II.xviii.600-4, quotation on 603. Hereafter cited parenthetically by book / chapter / page number.

4 See Collington, 'Othello the Liar,' The Mysterious and Foreign in Early Modern England, ed Helen Ostovich, Mary V. Silcox and Graham Roebuck (forthcoming from Newark, 2006). Bacon's categories are from 'Of Simulation and Dissimulation' (VI.18-21).

5 Zagorin, Ways of Lying: Dissimulation, Persecution, and Conformity in Early Modern Europe (Cambridge, MA, 1990), 3.

6 Bradley, Shakespearean Tragedy: Lectures on Hamlet, Othello, King Lear, Macbeth (1904; rpt London, 1964), 152-3.

7 T.W. Baldwin, 'A Note upon William Shakespeare's Use of Pliny', Essays in Dramatic Literature: The Parrott Presentation Volume, ed Hardin Craig (1935; rpt New York, 1967), 157-82; Kenneth Muir, 'Holland's Pliny and "Othello", Notes and Queries 198 (1953), 513-14, and Muir, The Sources of Shakespeare's Plays (London, 1977), 186-90.

8 Pliny, Selections from The History of the World Commonly Called The Natural History of C. Plinius Secundus, trans Philemon Holland, ed Paul Turner (Carbondale, IL, 1962), VII.69-89; hereafter cited parenthetically by book / page number.

9 Henry Burrowes Lathrop, Translations from the Classics into English from Caxton to Chapman 1477-1620 (Madison, WI, 1933), 219-20. Cf. Eldred D. Jones, Othello's Countrymen: The African in English Renaissance Drama (London, 1965); and Jones, The Elizabethan Image of Africa (Charlottesville, VA, 1971).

10 See Erasmus, De Copia, trans Betty I. Knott, Collected Works of Erasmus: Literary and Educational Writings 2, ed Craig R. Thompson (Toronto, 1978), 581. I am grateful to Patricia Parker for the reference. In Shakespeare from the Margins: Language, Culture, Context (Chicago, 1996), Parker examines Othello's reliance on enargeia / evidentia, terms which convey a range of verbal embellishments that increase the vividness of style and amplify the actual content of a given work (243-5). Joel B. Altman also examines this concept in his essay, "Preposterous Conclusions": Eros, Enargeia, and the Composition of Othello,' Representations 18 (Spring 1987), 129-57, 133-5; though he focuses on how Iago employs rhetorical devices to distort logic and conceal the truth.

11 For a biographical sketch of Pliny, his adventures, and his naval command, see Turner's introduction to Pliny, Selections from The History of the World, 7-8. 
12 Hodgen, Early Anthropology in the Sixteenth and Seventeenth Centuries (Philadelphia, 1964), esp chapters 5 and 6; Jones, The Elizabethan Image of Africa, passim. For a recent account of the awkward transition from (classical) 'marvelous' to (early modern) 'scientific' traditions in the writings of Montaigne and Bacon, see Peter G. Platt, Reason Diminished: Shakespeare and the Marvelous (Lincoln, NB, 1997), 36-65.

13 See Jones, The Elizabethan Image of Africa, 7, 14-31.

14 Burton, The Anatomy of Melancholy, ed Holbrook Jackson, 3 vols (1932; rpt London, 1948), 2:34-69, quotation on 40.

15 Thomas Dekker, Patient Grissil (1603), The Dramatic Works of Thomas Dekker, ed Fredson Bowers, 4 vols (Cambridge, 1970), 2:278 (5.1.18-50).

16 Brome, The Antipodes, Three Renaissance Travel Plays, ed Anthony Parr (Manchester, 1995), 1.1.176-81; hereafter cited parenthetically.

17 Cf the sample illustrations under the proverb 'A TRAVELLER may lie with authority' in Morris Palmer Tilley, Elizabethan Proverb Lore in Lyly's Euphues and in Pettie's Petite Palace with Parallels from Shakespeare (New York, 1926), 308 (\# 639); and R.W. Dent, Shakespeare's Proverbial Language: An Index (Berkeley, CA, 1981), 236 (\# T476). See also Hodgen, Early Anthropology, 183-4 and sources cited there. For a fascinating survey, see Sara Warneke, 'Educational Travellers: Popular Imagery and Public Criticism in Early Modern England', Journal of Popular Culture 28 (1994): 71-94.

18 Shakespeare, The Tempest, ed Frank Kermode, Arden 2 (1954; rpt London, 1994), 3.3.44-9, hereafter cited parenthetically.

19 Writing in 1710, the Earl of Shaftesbury mocked Othello as 'full fraught with Prodigy: a wondrous Story-teller', and expressed sympathy for a Desdemona so easily duped by his tales: 'What passionate reader of Travels, or Student in the prodigious Sciences, can refuse to pity that fair Lady, who fell in Love with the miraculous Moor? especially considering with what sutable grace such a Lover cou'd relate the most monstrous Adventures .... Seriously, 'twas a woful tale! unfit, one wou'd think, to win a tender Fair-one'. Cited in Horace Howard Furness, ed, Othello, New Variorum ed (1886; rpt Philadelphia, 1914), 57, italics in original.

20 Furness, ed, Othello, 57.

21 Hadfield, Literature, Travel, and Colonial Writing in the English Renaissance 1545-1625 (1998; rpt Oxford, 2001), 233-4.

22 Lim, The Arts of Empire: The Poetics of Colonialism from Ralegh to Milton (Newark, 1998), 112. 
23 Ralegh, The Discoverie of the Large, Rich, and Beautfull Empire of Guiana (1595), Voyages, ed Richard Hakluyt, Everyman ed, 8 vols (1907; rpt London, 1962), 7.328. This puzzling account of the Ewaipanoma is mentioned in nearly every modern examination of the Elizabethan fascination with foreign marvels; eg see G.K. Hunter, 'Elizabethans and Foreigners' Dramatic Identities and Cultural Tradition: Studies in Shakespeare and His Contemporaries (New York, 1978), 7.

$24 \mathrm{Lim}$, The Arts of Empire, 58, 121-2. Ralegh's reporting of the children's confirmation of these tales seems ironic; otherwise his account would be tantamount to a modern astronaut swearing that little green men live on the moon because children insisted they did.

25 On the explosion of interest in revisionary accounts of Africa among Shakespeare's contemporaries, see Hodgen, Early Anthropology; Jones, Othello's Countrymen; Elliot H. Tokson, The Popular Image of the Black Man in English Drama, 1550-1688 (Boston, 1982); Anthony Gerard Barthelemy, Black Face Maligned Race: The Representation of Blacks in English Drama from Shakespeare to Southerne (Baton Rouge, LA, 1987); Jack D’Amico, The Moor in English Renaissance Drama (Tampa, FL, 1991); Kim F. Hall, Things of Darkness: Economies of Race and gender in Early Modern England (Ithaca, NY, 1995); and Virginia Mason Vaughan, Othello: A Contextual History (1994; rpt Cambridge, 1996).

26 See the definition of rite as a custom or practice of a formal kind in The Oxford English Dictionary, compact ed, 3 vols (1971; rpt Oxford, 1987), sb.1.b. The sexual undertones are noted in Norman Sanders's gloss on 1.3.253 in the New Cambridge ed of Othello (1984; rpt Cambridge, 1989), 79.

27 Hodgen, Early Anthropology, 183; Jones, The Elizabethan Image of Africa, 31.

28 See Wright's chapter, 'The Wonder's of Travel', Middle-Class Culture in Elizabethan England (1935; rpt Ithaca, NY, 1958), 508.

29 Barnaby Rich, Faultes Faults, And Nothing Else but Faultes (1606), cited in Wright, Middle-Class Culture, 509.

30 John Stell, dedication to Nicholas de Nicholai's Nauigations, Peregrinations and Voyages Made into Turkie by Nicholas Nicholay Daulphinois (1585), cited in Wright, Middle-Class Culture, 509.

31 Marlowe, Edward II, The Complete Plays, ed J.B. Steane (1969; rpt London, 1986), 1.1.31-2.

32 On Othello's egotistical 'habit of self-approving self-dramatization', see F.R. Leavis, 'Diabolic Intellect and the Noble Hero: Or The Sentimentalist's Othello', The Common Pursuit (1952; rpt London, 1965), 136-59 (quotation 
on 142). Studies of Othello's narrative self include Marjorie Pryse, 'Lust for Audience: An Interpretation of Othello', English Literary History 43 (1976), 461-77; Stephen Greenblatt, Renaissance Self-Fashioning from More to Shakespeare (Chicago, 1980), 222-54; and James L. Calderwood, The Properties of Othello (Amherst, MA, 1989), 53-70.

33 Shakespeare, Troilus and Cressida, ed Kenneth Palmer, Arden 2 ed (1982; rpt London, 1991), 3.3.115-17, hereafter cited parenthetically.

34 Samuel Johnson, 'Notes on Shakespeare: Othello', Selected Writings, ed Patrick Cruttwell (1968; rpt London, 1986), 304.

35 George Puttenham, The Arte of English Poesie, English Renaissance Literary Criticism, ed Brian Vickers (Oxford, 1999), 190-296, quotation from Book 3, Chapter 10 (237). Puttenham's complaint concerns the hankering for 'novelties' in rhetorical forms, but that this phenomenon extended to the content of stories too is confirmed by Sara Warneke, 'A Taste for Newfangledness: The Destructive Potential of Novelty in Early Modern England', The Sixteenth Century Journal 26 (1995), 881-96.

36 Erasmus, De Copia, 302.

37 The phrase is from Calderwood, The Properties of Othello, 63.

38 Adelman, 'Iago's Alter Ego: Race as Projection in Othello,' Shakespeare Quarterly 48 (1997), 127-8.

39 See Honigmann's Arden 3 ed, Othello, gloss and textual notes to 1.3.140.

40 Marion Wynne-Davies, ed, The Renaissance: A Guide to English Renaissance Literature: 1500-1660 (London, 1992), 276 (italics omitted). For detailed definitions and examples of 'travel lies' in the later seventeenth century and after, see Percy G. Adams, Travelers and Travel Liars 1660-1800 (1962; rpt New York, 1980), esp. 1-18.

41 More, Utopia (1516), trans Edward Surtz, SJ, The Longman Anthology of British Literature, ed David Damrosch, vol 1 (New York, 1999), 638.

42 Womack, 'The Writing of Travel,' A Companion to English Renaissance Literature and Culture, ed Michael Hattaway (Oxford, 2000), 148.

43 New Cambridge editor Sanders and Arden 2 editor M.R. Ridley opt for variants of the 1622 Quarto reading of 'travels'; see Sanders, ed Othello, New Cambridge ed, 1.3.138; Ridley, ed Othello, Arden 2 (1958; rpt London, 1986), 1.3.139.

44 See, respectively, John A. Hodgson, 'Desdemona's Handkerchief as an Emblem of Her Reputation', Texas Studies in Language and Literature 19 (1977), 313-22; Harry Berger, Jr, 'Impertinent Trifling: Desdemona's Handkerchief, Shakespeare Quarterly 47 (1996), 235-50; and Lynda E. Boose, 'Othello's 
Handkerchief: "The Recognizance and Pledge of Love", English Literary Renaissance 5 (1975), 360-74.

45 Vaughan, Othello: A Contextual History, 33 and note 61. The OED defines 'mummy' as 'a rich brown bituminous pigment' but the earliest citation for this usage is from the mid-nineteenth century (sb. 2d). In Othello's Countrymen, Jones answers 'no' to his question, proposing that the story is fabricated to conceal Othello's 'disproportionate passion over such a trifle' (102).

46 Hodgson seems skeptical of the first version, stating that it is a 'wild story' arbitrarily concocted to make a more resonant symbol of wifely fidelity; 'Desdemona's Handkerchief, 315. Honigmann proposes that the first story may have been invented to frighten Desdemona, but concedes that the contradiction may also stem from an 'oversight' (without specifying whose: Othello's? Shakespeare's?); Arden 3, note to 5.2.215. Cf the comments supporting version 2 cited in Furness's New Variorum ed of Othello, note to 5.2.269.

47 Mullaney, 'Strange Things, Gross Terms, Curious Customs: The Rehearsal of Cultures in the Late Renaissance,' Representations 3 (Summer 1983), 40-2.

48 Followed by the Germans, the Dutch, and possibly the Italians; see Harold Jenkins, ed, Hamlet, Arden 2 ed (1982; rpt London, 1987), longer notes to 1.4.12-13, 1.4.17-20, and 1.4.23-38 (447-8, and sources cited there).

49 Rymer, A Short View of Tragedy, 222.

50 Rymer, A Short View of Tragedy, 223.

51 See Ridley, ed, Othello, Arden 2, 5.2.254 note; Sanders, ed, Othello, New Cambridge, 5.2.251; and Honigmann, ed, Othello, Arden 3, 5.2.251 longer note ( $\mathrm{p} 341$ ). Furness prefers the Quarto reading, though for the wrong reason: 'I doubt whether "ice-brooks" are usual in the climate of Spain'; Othello, New Variorum ed, 5.2.315 note.

52 Count Baldassare Castiglione, The Book of the Courtier, trans Thomas Hoby (1561), ed Virginia Cox, Everyman (London, 1994), II.xli.149 and II.xviii.121.

53 Machiavelli, The Prince, trans Edward Dacres, 1640; Three Renaissance Classics, ed Burton A. Milligan (New York, 1953), 1-101, quotation on 83.

54 Sanders, ed, Othello, New Cambridge, supplementary note to 5.2.343 (191-2). Honigmann notes that the 'Indian' version can be traced back to Pliny's History (XXXIV.17), reason enough to take this assertion with a grain of salt (Arden 3 Othello, long note to 5.2.345, 342-3).

55 Greenblatt, Renaissance Self-Fashioning, 245, 238.

56 Calderwood, The Properties of Othello, 57-9. 
57 Calderwood, The Properties of Othello, 59.

58 Montaigne, 'It Is Follie to Referre Truth or Falshood to our Sufficiencie', I.xxvi.143. In French, the passage reads 'il n'est si petit escolier qui ne le convainque de mensonge', suggesting that a mere schoolboy, not Florio's poor study, can spot Pliny's lies; see Montaigne, Essais, ed Maurice Rat, 2 vols (Paris, 1962), I.xxvii in that edition (1.96).

59 Montaigne, 'Of the Force of Imagination', I.xx.64. The bull-baiting tale is attributed to Pliny by M.A. Screech in his edition of The Complete Essays, by Michel de Montaigne, Penguin Classics (1987; rpt London, 1991), 110 note 5.

60 Eg neither James Hirsh, 'Othello and Perception', in Othello: New Perspectives, ed Virginia Mason Vaughan and Kent Cartwright (Madison, NJ, 1991), 135-59, nor Katharine Eisaman Maus, 'Horns of Dilemma: Jealousy, Gender, and Spectatorship in English Renaissance Drama', English Literary History 54 (1987), 561-83, link the issue of misinterpretation to the limits of proto-anthropological observation so central in the play.

61 See Appendix 4 of Honigmann, ed Othello, Arden 3, 388-9, item 1. 